\title{
ON THE SUCCESSION OF SARMATIAN POPULATION IN THE EAST- EUROPEAN STEPPES
}

\author{
Mariya A. Balabanova \\ Doctor of Sciences (History), Professor, \\ Volgograd State University \\ mary_balabanova@mail.ru \\ Prosp. Universitetsky, 100, 400062 Volgograd, Russian Federation
}

\begin{abstract}
As V.P. Alekseev wrote, the succession of population has been peculiar for individual territories for centuries. Despite the fact that the Eastern European steppe in ancient times and the Middle Ages was characterized by frequent changes of the population due to its high dependence on the environmental conditions, the Sarmatian culture preservation was observed over a period of ceremonial standards and elements of material culture.

In this paper an attempt is made to show the presence of a partial succession of the three chronological periods of Sarmatian population. To do this, the author conducted a comparative characteristic of physical types of nomads of Sarmatian steppes of the Eastern Europe. The results of the study of mass craniological material combined in the cultural and chronological groups, showed that on the whole range of time and space over the steppe habitat Sarmatian cultures fixed partial similarity in physical type.

In this connection, it is assumed that the partial continuity of anthropological types of different cultural, historical and local groups is linked to: 1) partial preservation of substrate Early Sarmatian population over the 4th3rd centuries $\mathrm{BC}$ - first half of 2nd-4th centuries AD; 2) the direction and character of penetration of nomadic groups who migrated from the East into steppe space; 3) design of a single system of seasonal migrations which involves the presence of winter and summer camps, and the presence of burial mounds; 4) the inclusion of a horde of nomadic pastoral population groups moved all over the steppes, from between Volga and Ural to the Lower Don; 5) the fact that male migrants married local women.

Key words: Sarmatians, early nomads, anthropological type, longitudinal diameter, migration, continuity, substrate.
\end{abstract}

\section{К ВОПРОСУ О ПРЕЕМСТВЕННОСТИ НАСЕЛЕНИЯ САРМАТСКОГО ВРЕМЕНИ ВОСТОЧНО-ЕВРОПЕЙСКИХ СТЕПЕЙ}

\footnotetext{
Мария Афанасьевна Балабанова

Доктор исторических наук, профессор,

Волгоградский государственный университет

mary balabanova@mail.ru

просп. Университетский, 100, 400062 г. Волгоград, Российская Федерация

Аннотация. В данной работе делается попытка показать наличие частичной преемственности у сарматского населения трех хронологических периодов. Для этого проводилась сравнительная характеристика антропологических типов кочевого населения сарматского времени степей Восточной Европы. Результаты исследования массового краниологического материала, объединенного в культурно-хронологические группы, показали, что на всем временном диапазоне и на протяжении степных пространств ареала сарматских культур фиксируется частичное их сходство в антропологическом типе.

В связи с этим предполагается, что частичная преемственность антропологических типов различных культурно-исторических и локальных групп связана: 1) с сохранением какой-то части субстратного ранне-
} 
сарматского населения на протяжении IV-III вв. до н. э. - первой половины II-IV вв. н. э.; 2) с направлением и характером проникновения в степные пространства кочевнических групп, мигрировавших с востока; 3) с оформлением единой системы сезонных перекочевок, которые предполагали наличие зимних и летних стойбищ и наличие могильников при них; 4) с включением в кочевую орду переселившихся групп скотоводческого населения на всем протяжении степей, от междуречья Волги и Урала до Нижнего Дона; 5) с тем, что мужчины-мигранты заключали браки с местными женщинами.

Ключевые слова: сарматы, ранние кочевники, антропологический тип, продольный диаметр, миграция, преемственность, субстрат.

При изучении древнего и средневекового населения преемственность предполагает полное или частичное сохранение культурного комплекса и антропологического типа на определенной территории. Наличие преемственности позволяет выявить черты сходства, особенно в такой консервативной области, как погребальный обряд, а на антропологических материалах иногда удается выделить субстратный компонент, который либо полностью, либо частично может сохраняться на протяжении многих столетий.

Еще в самом начале изучения сарматских древностей наличие сходства в хронологических культурных комплексах и в антропологическом облике позволило ученым сформулировать автохтонную гипотезу происхождения сарматских культур и населения $[10 ; 12 ; 25 ; 26]$.

Позднее, с накоплением материалов, этот вопрос изучался более детально. При этом наряду с преемственностью и субстратным компонентом стали выделять пришлый (суперстратный) компонент, который связывали с мигрантами - носителями культурных новаций. Они на изучаемой территории характеризовали новую культуру или период (среднесарматский, а затем и позднесарматский) $[1$, с. 110,$111 ; 3$, с. $224 ; 20$, с. $112-116$; 23, c. 172-179].

Согласно материалам семинара, посвященного проблемам соотношения раннесарматской и среднесарматской культур, первые новации появляются во II-I вв. до н. э., а впоследствии становятся определяющими для среднесарматской культуры $[9$, с. 60,$61 ; 11$, с. $69 ; 22$, с. 44,$45 ; 24$, с. 25 ]. В настоящее время вполне очевидно то, что с окончанием формирования среднесарматской культуры продолжают сохраняться традиции раннесарматской, что может объясняться сохранением старого населения в рамках новых этнополитических образований [3, с. 224, 225; 4, с. 119 ;
23 , с. $172-179 ; 24$, с. 20-25]. Региональная специфика формирования среднесарматского культурного комплекса позволяет соглашаться с мнением волгоградских археологов о том, что в отдельных регионах, а именно в ВолгоДонском, некоторые раннесарматские культурные традиции не исчезают вплоть до рубежа эр и даже встречаются в I в. н. э., поэтому порой сложно разграничить погребения раннесарматской и среднесарматской культур [13, c. $85 ; 21$, с. $89 ; 24$, с. 25$]$.

В свое время это послужило поводом для выделения погребений с «размытой» культурной атрибутикой или обозначения их как раннего периода среднесарматской культуры. Морфологический тип таких групп: одна - из могильника Калиновка, а другая, опубликованная Е.Ф. Батиевой как группа из погребений Нижнего Дона I в. до н. э. - I в. н. э., отличается в этих группах от типичной раннесарматской тем, что у них мозговой отдел большей длины и высоты, а лицевой отдел имеет грацильное строение $[1$, с. $108 ; 5$, с. 60$]$.

Среднесарматские культурные традиции также недолговечны и с распространением позднесарматской культуры в восточноевропейских степях происходит отказ от многих обрядовых норм. Внедрение новых культурных традиций на сарматских территориях по времени протекало по-разному. Как показывает материал, в междуречье Волги и Дона традиции среднесарматской культуры сохраняются до конца II в. н. э., а преобладание позднесарматского культурного комплекса происходит только к концу II началу III в. [15, с. 124-132].

Специфика материалов Нижнего Дона показывает, что здесь с середины III в. распространяются погребальные памятники, своим происхождением непосредственно не связанные с позднесарматской культурой. В погребальной обрядности преобладают катаком- 
бы под курганной насыпью, которые обнаруживают близкие аналогии с раннеаланскими материалами Северного Кавказа. Эти культурные новации ряд авторов объясняет появлением на Нижнем Дону нового этнического компонента. Что касается позднесарматских памятников междуречья Волги и Дона, то они продолжают существовать и после середины III в., видимо, вплоть до нашествия гуннов [7, c. 112,$113 ; 14$, c. 83,$84 ; 16$, c. $49 ; 17$, c. $127-$ $130 ; 19$, с. 144,145$]$.

Хотя и не всегда, но очень часто культурные изменения являются отражением притока новых групп населения. При таком раскладе возникает вопрос о соотношении субстратных и пришлых групп, который можно попытаться решить с помощью антропологического исследования с использованием массового материала. При выяснении соотношения мигрантного и местного населения использовались статистические методы анализа краниометрических признаков. Суммарная серия насчитывает 803 черепа II-I вв. до н. э. - второй половины II - IV в. н. э.

На первом этапе сравнительный анализ проводился поочередно между сарматскими группами по $t$-критерию Стьюдента. На втором этапе проводился межгрупповой многомерный анализ (пакет программ Б.Г. Козинцева) раннесарматских, среднесарматских и позднесарматских серий из отдельно взятых могильников.

\section{Сравнительная характеристика} краниологических серий

\section{раннесарматского и среднесарматского} времени

Мужские серии. Для сопоставления использовались серии раннесарматского и среднесарматского времени, насчитывающие 200 и 180 черепов. По результатам сравнительного анализа по $t$-критерию Стьюдента у мужчин оказалось семь признаков с достоверно значимыми различиями. Данные признаки описывают изменчивость как мозгового отдела черепа (пять признаков), так и лицевого (два признака): это продольный и высотный диаметры; высотно-поперечный указатель; общеростовая величина; лобный указатель, зигомаксилярный угол и общий лицевой угол (1,
17, 17:8, ОРВ, 9:10, <zm', 72) (табл. 1). Согласно этим данным, черепная коробка в мужской серии среднесарматского времени длиннее, массивнее и выше, чем в раннесарматской, а лицевой отдел по линии зигомаксилярных точек слабее профилирован, по линии назионпростион с тенденцией к мезогнатии.

Как сходство, так и различие части разновременного мужского населения очевидны при сопоставлении краниологических групп каноническим методом (рис. 1). Всего в анализ было включено 24 раннесарматских и 19 среднесарматских групп, полученных из материалов одного могильника.

Результаты анализа показали, что ряд серий раннесарматского и среднесарматского времени из одного могильника демонстрирует отчетливое сходство: это материалы могильников из Калиновки, Бережновки II, Нового, Первомайского, Перегрузного I (рис. 1).

Говоря о субстратном и пришлом компонентах у населения среднесарматской культуры, нельзя обойти вниманием ту группу, которая получена из комплексов, характеризующихся диагональным типом захоронений. Данная погребальная практика в это время является новацией и продолжает существовать вплоть до первой половины III в. н. э. Серия краниологических материалов «диагональников» оказалась чрезвычайно неоднородной. Несмотря на это, в группе преобладают тип с брахикранными пропорциями, который характеризует облик субстратного раннесарматского населения [2, с. 84]. Брахикранный тип отмечается у половины черепов мужской части из диагональных погребальных комплексов. Такое распределение брахикранов сохраняется и у поздней группы второй половины II - первой половины III в. н. э., не практиковавшей обычай искусственной деформации, из диагональных комплексов. Локальная изменчивость, присущая группам из подобных комплексов, позволяет выделить две мужские серии, в которых преобладает тип предполагаемых мигрантов - тип длинноголовых европеоидов, это группы из Заволжья и Волго-Донского междуречья. Видимо, практика диагонального обряда в этих регионах больше была характерна для пришлого населения, нежели для субстратного [2, с. 85]. 
Значимые различия при сравнении суммарных мужских серий сарматского времени

\begin{tabular}{|c|c|c|c|c|c|c|c|c|c|}
\hline \multirow{2}{*}{$\begin{array}{c}\text { № по } \\
\text { Матрину } \\
\text { и др. }\end{array}$} & \multicolumn{3}{|c|}{$\begin{array}{c}\text { II-I вв. до н. э. - } \\
\text { I - первая половина II в. н. э. }\end{array}$} & \multicolumn{3}{|c|}{$\begin{array}{c}\text { II-І вв. до н. э.- } \\
\text { вторая половина II - IV в. н. э. }\end{array}$} & \multicolumn{3}{|c|}{$\begin{array}{c}\text { I - первая полови на II в. - } \\
\text { вторая половина II - IV в. н. э. }\end{array}$} \\
\hline & $\bar{k}$ & $\begin{array}{l}t \text {-крит е- } \\
\text { рий }\end{array}$ & Значимость & $k$ & $\begin{array}{l}t \text {-крите- } \\
\text { рий }\end{array}$ & Значимость & $k$ & $\begin{array}{l}t \text {-крите- } \\
\text { рий }\end{array}$ & Значимость \\
\hline 1 & 347 & 2,122 & $p>0,05$ & 279 & 3,978 & $p>0,001$ & 262 & 1,889 & \\
\hline 8 & 341 & 0,933 & & 274 & 6,353 & $p>0,001$ & 261 & 5,316 & $p>0,001$ \\
\hline $8: 1$ & 335 & 1,483 & & 270 & 6,492 & $p>0,001$ & 258 & 4,653 & $p>0,001$ \\
\hline 17 & 235 & 2,030 & $p>0,05$ & 212 & 3,853 & $p>0,001$ & 185 & 1,929 & \\
\hline $17: 8$ & 231 & 1,991 & $p>0,05$ & 206 & 6,814 & $p>0,001$ & 183 & 4,464 & $p>0,001$ \\
\hline OPB & 230 & 2,161 & $p>0,05$ & 206 & 1,125 & & 184 & 0,805 & \\
\hline $\mathrm{M} 2$ & 335 & 0,655 & & 260 & 2,645 & $p>0,01$ & 247 & 3,117 & $p>0,01$ \\
\hline УПИЛ & 239 & 1,274 & & 227 & 1,919 & & 174 & 3,039 & $p>0,01$ \\
\hline $9: 8$ & 330 & 1,498 & & 266 & 4,540 & $p>0,001$ & 252 & 3,185 & $p>0,01$ \\
\hline $9: 10$ & 258 & 2,093 & $p>0,05$ & 222 & 4,614 & $p>0,001$ & 220 & 2,643 & $p>0,01$ \\
\hline 10 & 260 & 1,274 & & 224 & 5,124 & $p>0,001$ & 224 & 4,170 & $p>0,001$ \\
\hline 11 & 282 & 1,450 & & 238 & 1,412 & & & 2,375 & $p>0,01$ \\
\hline $45: 8$ & 289 & 1,293 & & 214 & 5,471 & $p>0,001$ & 228 & 4,379 & $p>0,001$ \\
\hline 77 & 354 & 1,028 & & 289 & 1,464 & & 259 & 2,167 & $p>0,05$ \\
\hline$<\mathrm{zm}$ ' & 317 & 2,124 & $p>0,05$ & 264 & 0,982 & & 237 & 2,683 & $p>0,01$ \\
\hline 32 & 276 & 1,795 & & 233 & 3,767 & $p>0,001$ & 205 & 1,992 & $p>0,05$ \\
\hline 72 & 269 & 2090 & $p>0,05$ & 230 & 1,705 & & 199 & 0,189 & \\
\hline
\end{tabular}

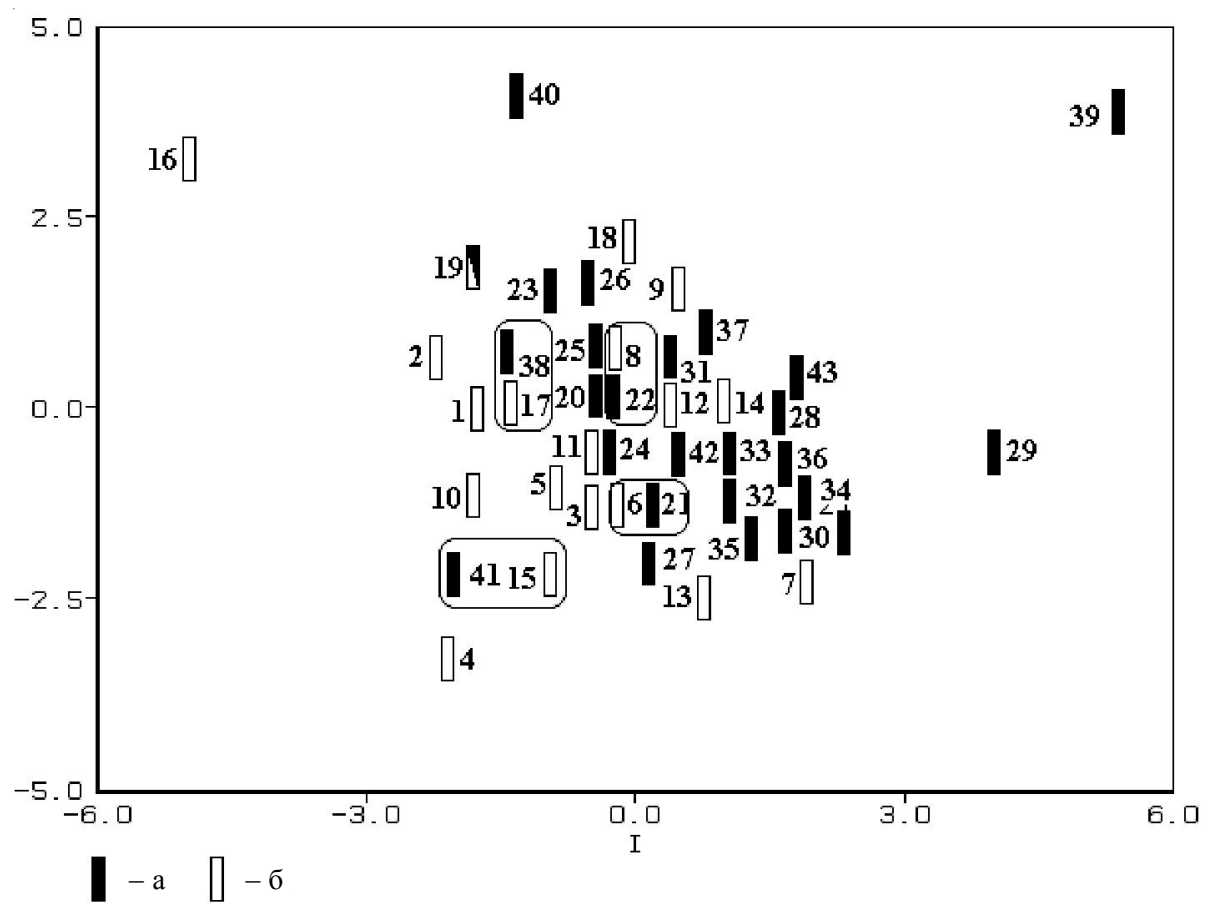

Рис. 1. Результат многомерного неметрического шкалирования и кластерного анализа расстояний Махаланобиса мужских групп раннесарматского и среднесарматского времени

( $a$ - серии раннесарматского времени; $\sigma$ - серии среднесарматского времени; объединены серии из одного могильника, образующие один кластер):

Серии среднесарматского времени: 1 - Терновский; 2 - Первомайский; 3 - Бережновка-I; 4 - Кузин; 5 - Кривая Лука; 6 - Калиновка; 7 - Быково; 8 - Бережновка-II; 9 - Старица; 10 - Канал Волга-Чограй; 11 - Жутово; 12 - Эвдык;

13 - Аккермень; 14 - Усть-Каменка; 15 - Новый; 16 - Колобовка; 17 - Перегрузное I; 18 - Аксай; 19 - Калиновка *

Серии раннесарматского времени: 20 - Быково; 21 - Калиновка-1; 22 - Бережновка; 23 - Верхний Балыклей;

24 - Старица; 25 - Батаевка; 26 - Степной IV; 27 - Киляковка; 28 - Старые Киишки; 29 - Мечет Сай; 30 - Новый Кумак; 31 - Первомайский; 32 - Калмыково; 33 - Кара Оба; 34 - Эльтон; 35 - Кривая Лука; 36 - Верхнепогромное; 37 - Политотдельское; 38 - Перегрузное I; 39 - Колобовка; 40 - Маляевка; 41 - Новый; 42 - Аксай; 43 - Прохоровка

Примечание. * Группа из погребений с «размытой» культурной атрибутикой. 
Таким образом, если предположить, что носителями диагонального обряда были мигранты, относящиеся к типу длинноголовых европеоидов, то присутствие его в группе широкоголовых европеоидов предполагает освоение этой обрядовой практики местным населением.

Результаты вышеприведенного сравнения позволяют говорить о том, что формирование среднесарматской антропологической мужской формации связано с сохранением субстратного раннесарматского компонента и включением пришлого компонента, сочетающего долихокранию с ослабленной горизонтальной профилировкой лицевого скелета.

Женские серии. Сравнивались хронологические женские группы численностью 171 и 116 черепов. Проверка статистической значимости параметров регрессионного уравнения, выполненного по $t$-критерию Стьюдента, показала значимые различия по шести признакам лицевого отдела черепа: это высота лица и носа; лицевой и орбитный указатели; максилофронтальная высота и ширина $(48,48: 45$, 55, 52:51, MC, MS). Все вышеперечисленные размеры больше в среднесарматской серии (табл. 2).

В женской среднесарматской серии из диагональных комплексов доля черепов с брахикранными пропорциями значительно выше, чем в мужской, около 70,0 \% [2, с. 84].

Результаты канонического анализа 20 ceрий раннесарматского и 15 среднесарматского времени показывают, что привнесение какого-то длинноголового варианта в женскую субстратную среду I - первой половины II вв. н. э. практически незаметно. Иллюстрацией этому служит тот факт, что все серии, раннесарматские, среднесарматские и серии с «раз- мытой» культурной атрибутикой, сформированные из материалов могильников Калиновка и нижнедонского региона, обладают большим сходством (рис. 2). Показатели попарных расстояний близости по Махаланобису также свидетельствуют о большом сходстве женской части населения первых двух периодов сарматской эпохи.

\section{Сравнительная характеристика раннесарматского (II-I вв. до н. э.) и позднесарматского времени}

Мужские серии. Для статистической проверки равенства средних значений двух серий: раннесарматского времени, насчитывающей 200 черепов, и позднесарматского времени без следов искусственной деформации, насчитывающей 105 черепов, - рассчитывалось значение $t$-критерия Стьюдента. В результате проведенной процедуры оказалось, что достоверно значимые различия выявились по 11 признакам (см. табл. 1). Почти все эти признаки отражают изменчивость размеров мозговой коробки и их указателей. Это: продольный, поперечный, высотный диаметры, наибольшая ширина лба и условное трансверсальное сечение $(1 ; 8 ; 17 ; 10 ; \mathrm{M} 2)$; черепной; высотно-поперечный; лобно-поперечный; широтный лобный; поперечный фацио-церебральный $(8: 1 ; 17: 8 ; 9: 8 ; 9: 10 ; 45: 8)$ указатели. Значимые различия наблюдаются и по углу профиля лба от назиона (32), что, скорее всего, связано с наличием в позднесарматской выборке черепов со следами слабой лобной или лобно-затылочной деформации, на которых лоб наклонный. Следует отметить, что такое распределение различий вполне объяснимо, так как сравниваемые хронологические

Таблица 2

Значимые различия при сравнении суммарных женских серий сарматского времени

\begin{tabular}{|c|c|c|c|c|c|c|c|c|c|}
\hline $\begin{array}{c}\text { № по по } \\
\text { Матрину } \\
\text { и др. }\end{array}$ & \multicolumn{3}{|c|}{ II-І вв. до н. э.- } & \multicolumn{3}{|c|}{ II-І вв. до н. э. - } & \multicolumn{3}{|c|}{ I - первая половина II в. - } \\
\cline { 2 - 11 } & $k$ & $\begin{array}{c}t \text {-крите- } \\
\text { рий }\end{array}$ & Значимость & $k$ & $\begin{array}{c}t \text {-крите- } \\
\text { рий }\end{array}$ & Значимость & $k$ & $\begin{array}{c}t \text {-крите- } \\
\text { рий }\end{array}$ & Значимость \\
\hline $9: 10$ & 216 & 1,201 & & 151 & 2,210 & $p>0,05$ & 115 & 1,556 & \\
\hline 48 & 257 & 2,328 & $p>0,05$ & 180 & 0,338 & & 127 & 0,984 & \\
\hline $48: 45$ & 226 & 2,289 & $p>0,05$ & 162 & 0,746 & & 112 & 0,572 & \\
\hline 55 & 259 & 2,454 & $p>0,05$ & 181 & 0,146 & & 128 & 1,423 & \\
\hline $52: 51$ & 260 & 2,097 & $p>0,05$ & 177 & 1,223 & & 131 & 0,000 & \\
\hline MC & 224 & 2,018 & $p>0,05$ & 149 & 0,791 & & 119 & 2,108 & $p<0,05$ \\
\hline MS & 208 & 2,839 & $p>0,05$ & 139 & 0,325 & & 109 & 1,830 & \\
\hline
\end{tabular}




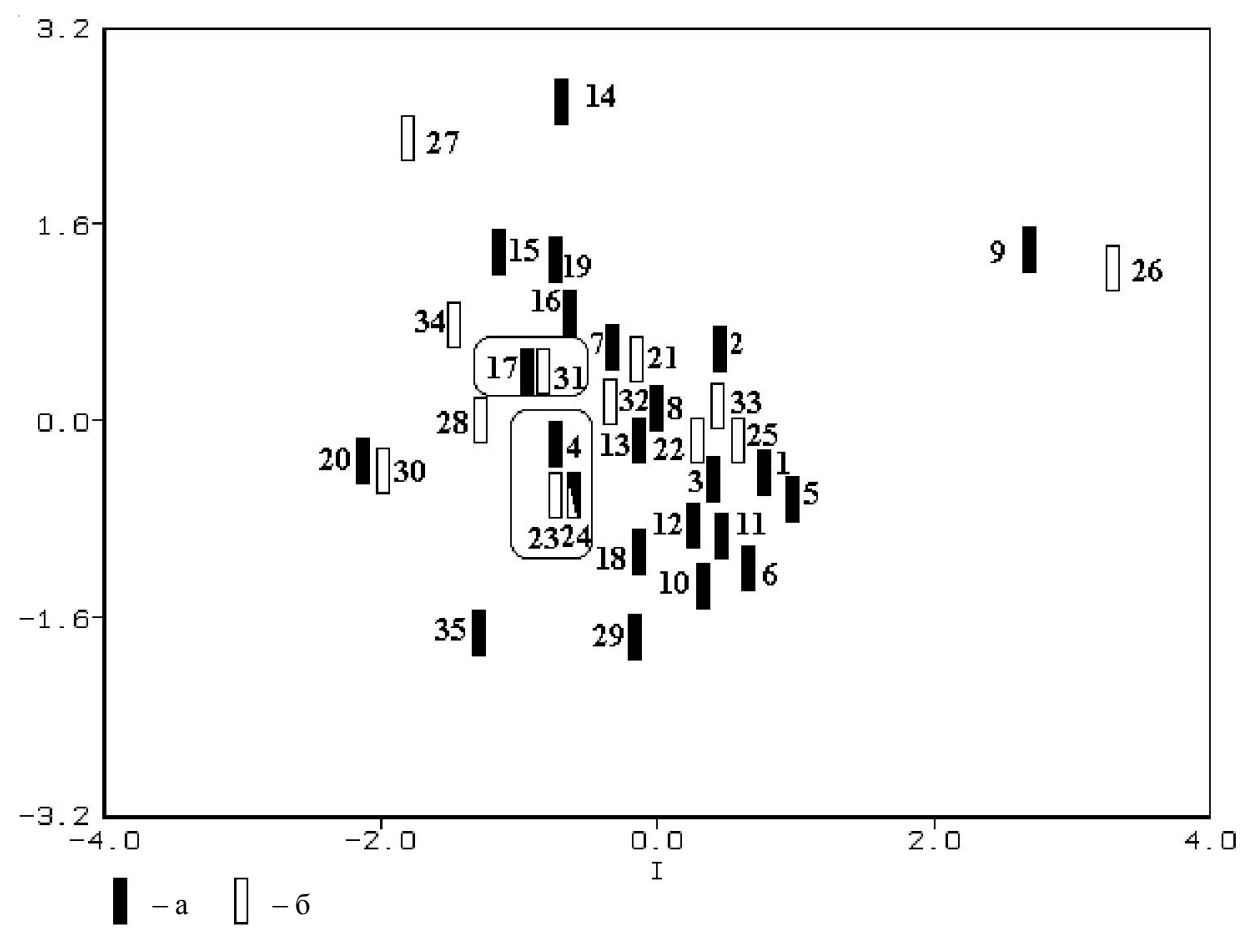

Рис. 2. Результат многомерного неметрического шкалирования и кластерного анализа расстояний Махаланобиса женских групп раннесарматского и среднесарматского времени (обозначения на рис. 1 и 2 совпадают)

Серии раннесарматского времени: 1 - Богодушанский Ерик; 2 - Первомайский; 3 - Старица; 4 - Калиновка; 5 - Бережновка-II; 6 - Быково; 7 - Кривая Лука; 8 - Верхний Балыклей; 9 - Степной IV; 10 - Старые Киишки; 11 - Мечет Сай; 12 - Калмыково; 13 - Нижнедонская; 14 - Верхнепогромное; 15 - Красный Октябрь; 16 - Царев; 17 - Перегрузное I; 18 - Солодовка; 19 - Авиловский; 20 - Ковалевка.

Серии среднесарматского времени: 21 - Бережновка I; 22 - Бережновка II; 23 - Калиновка; 24 - Калиновка 1; 25 - Крепь; 26 - Первомайский; 27 - Старица; 28 - Нижнедонская; 29 - Ново-Филипповка; 30 - Аккермень; 31 - Перегрузное I; 32 - Аксай; 33 - Терновский; 34 - Маляевка; 35 - Политотдельское

группы относятся к различным морфологическим типам: раннесарматское население - тип широкоголовых низкосводчатых европеоидов, у которых умеренно профилированное лицо на верхнем уровне, а позднесарматское - тип длинноголовых высокосводчатых европеоидов с резкой горизонтальной профилировкой.

Вышеприведенное направление межгрупповой изменчивости мужского населения раннего и позднего периодов более наглядно демонстрирует и многомерный анализ по 14 краниологическим признакам: продольному, поперечному и высотному диаметрам мозговой коробки, наименьшей ширине лба, скуловой ширине, верхней высоте лица, назомалярному и зигомаксилярному углам, ширине и высоте носа и орбиты, симотическому указателю и углу выступания лица.

В результате многомерного анализа 30 раннесарматских и 17 позднесарматских групп, не практиковавших обычай деформа- ции, оказалось, что I канонический вектор (далее КВ) отражает изменчивость между сериями, у которых, с одной стороны, широкая и низкосводчатая мозговая коробка, а с другой с узкая и высокосводчатая. Вклад в общую межгрупповую изменчивость I КВ значительный и составляет около 36,0 \%.

Средние значения по сериям показывают, что первый набор признаков характерен для раннесарматских серий, а второй - для позднесарматских. Ранжирование групп по нагрузкам I КВ показывает, что положительные значения имеют только раннесарматские серии, а отрицательные значения - позднесарматские серии, кроме немногих исключений. К ним можно отнести серии, локализованные на западе ареала раннесарматских памятников в Волго-Донском и Маныч-Сальском междуречьях (Перегрузное I, Новый и др.). В этих группах мозговая коробка по размерам поперечного диаметра минимальная среди синх- 
ронных групп, а высота свода - максимальная, и они занимают крайнее, западное положение в клинальном характере изменчивости этих признаков, что позволяет считать первую дискриминанту переменной, разграничивающей морфологические типы по культурно-хронологическим периодам: ранесарматскому и позднесарматскому.

Отчетливые различия в антропологическом облике мужского населения раннесарматского и позднесарматского времени демонстрирует и четырехпольный график многомерного неметрического шкалирования и дендрограмма кластеризации расстояний Махаланобиса (рис. 3). Расположение серий на корреляционном поле следующее. Большая часть позднесарматских мужских групп расположилась на отрицательном поле, а раннесарматских - на положительном.
Таким образом, сопоставление как суммарных хронологических мужских серий, так и серий из отдельно взятых могильников свидетельствует о значительном различии этих антропологических пластов. Видимо, на протяжении среднесарматского и позднесарматского времени миграции, связанные с носителями типа длинноголовых европеоидов, привели к «размыванию» субстратного раннесарматского компонента. Тем не менее есть три группы раннесарматского, среднесарматского и позднесарматского времени, у которых определенно наблюдается сходство в морфологическом облике. К ним следует отнести группы из могильников Волго-Донского междуречья: Перегрузное I и Первомайский - и группы из Маныч-Сальского междуречья - хутор Новый.

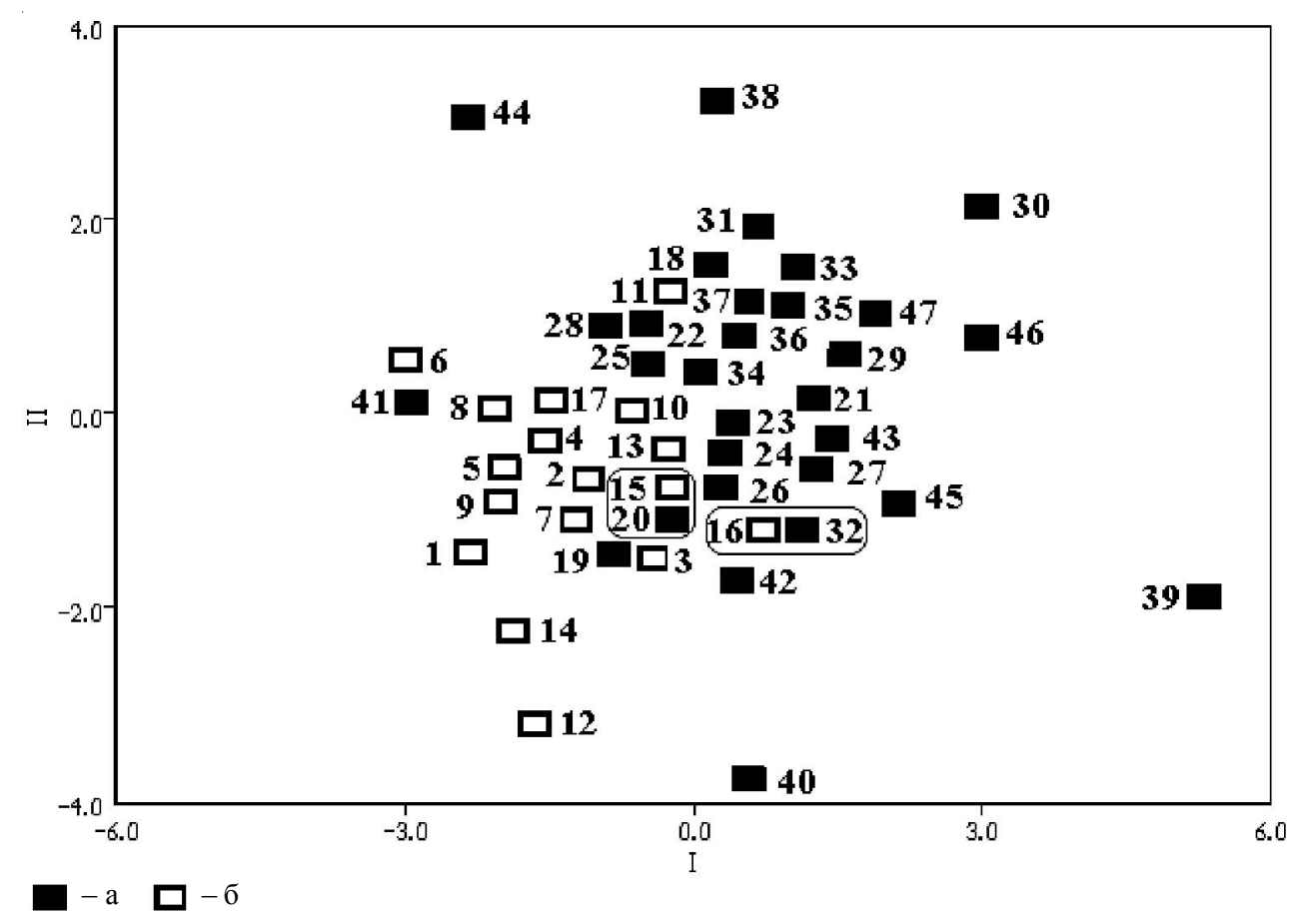

Рис. 3. Результат многомерного неметрического шкалирования расстояний близости по Махаланобису $\left(D^{2}\right)$ мужских краниологических серий раннесарматского и позднесарматского времени

( $a$ - серии раннесарматского времени; $\sigma$ - серии позднесарматского времени; объединены серии из одного могильника, образующие один кластер):

Серии недеформированных черепов позднесарматского времени: 1 - Кузин; 2 - Джангр; 3 - Кривая Лука; 4 - Старица;

5 - Бережновка; 6 - Бережновка-II; 7 - Бережновка-I; 8 - Калиновка; 9 - Купцын Толга; 10 - Канал Волга-Чограй;

11 - Цаган-Усн; 12 - Абганерово-II; 13 - Терновский; 14 - Аксай; 15 - Перегрузное-I; 16 - Первомайский; 17 - Нижнедонская.

Серии раннесарматского времени: 18 - Нижнедонская; 19 - Калиновка-1; 20 - Перегрузное-I; 21 - Быково;

22 - Калиновка-2; 23 - Бережновка; 24 - Верхний Балыклей; 25 - Старица; 26 - Батаевка; 27 - Степной-IV;

28 - Киляковка; 29 - Старые Киишки; 30 - Мечет Сай; 31 - Новый Кумак; 32 - Первомайский; 33 - Калмыково;

34 - Кара Оба; 35 - Эльтон; 36 - Кривая Лука; 37 - Верхнепогромное; 38 - Политотдельское; 39 - Колобовка; 40 - Маляевка; 41 - Новый; 42 - Племхоз; 43 - Царев; 44 - Солодовка; 45 - Лебедевка; 46 - Кардаилово; 47 - Прохоровка 
Женские серии. Оценка значимости различий по $t$-критерию Стьюдента оценивалась по средним значениям женских серий численностью 171 череп раннесарматского времени и 31 череп без практики искусственной деформации позднесарматского времени. В результате был обнаружен только один признак широтный лобный указатель (9:10) - с достоверно значимыми различиями (см. табл. 2). Такой результат сопоставления является свидетельством сохранения раннесарматского субстрата у женской части населения на протяжении всей сарматской истории - у той ее части, которая не практиковала обычай искусственной деформации. Результаты канонического анализа не противоречат этому выводу.

Во-первых, вклад I КВ в межгрупповую изменчивость значительно меньше, чем у анализируемых мужских групп, и составляет чуть больше $22,0 \%$ от общей изменчивости, что, на наш взгляд, демонстрирует большее сход- ство женского населения раннего и позднего хронологических пластов. Различия между группами по этой переменной наблюдаются по поперечному и продольному диаметрам и ширине орбиты. Основываясь на этих данных, легко заметить, что у раннесарматских групп преобладает короткая, широкая мозговая коробка и широкая глазница (положительный полюс изменчивости), а у позднесарматских длинная, узкая мозговая коробка и узкая глазница (отрицательный полюс изменчивости). Тем не менее в первую группу попадают позднесарматские группы, а во вторую - раннесарматские, которые происходят из могильников Волго-Донского междуречья (группы из Ковалевки, Перегрузного I и др.).

Расположение женских разновременных групп, которое демонстрирует дендрограмма кластерного анализа, не так сильно разобщено, как на графике многомерного неметрического шкалирования мужских групп (рис. 4).

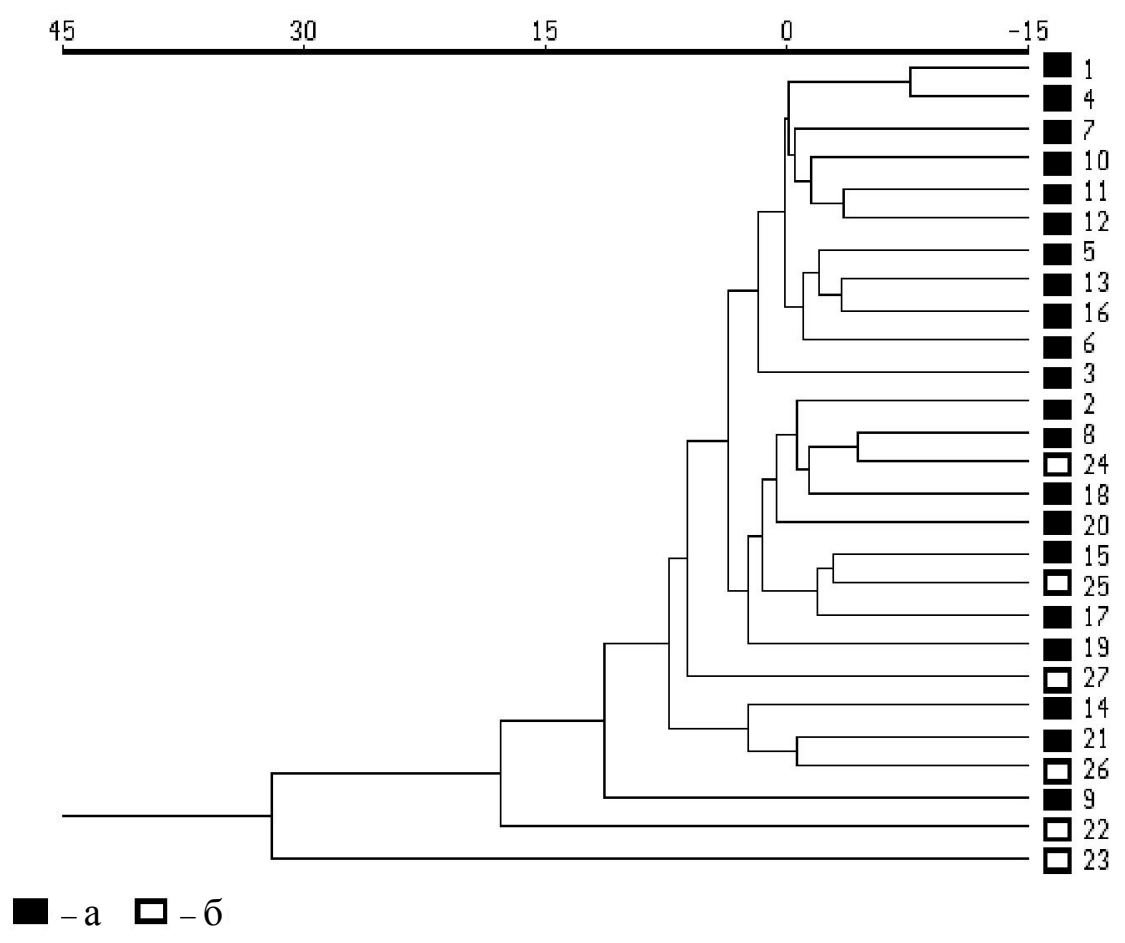

Рис. 4. Результат кластеризации расстояний близости по Махаланобису $\left(D^{2}\right)$ женских краниологических серий раннесарматского и позднесарматского времени ( $a$ - серии раннесарматского времени; $\sigma$ - серии позднесарматского времени):

Серии раннесарматского времени: 1 - Богодушанский Ерик; 2 - Первомайский; 3 - Старица; 4 - Калиновка;

5 - Бережновка-II; 6 - Быково; 7 - Кривая Лука; 8 - Верхний Балыклей; 9 - Степной-IV; 10 - Старые Киишки: 11 - Мечет Сай; 12 - Калмыково; 13 - Солодовка; 14 - Верхнепогромное; 15 - Красный Октябрь; 16 - Кардаилово; 17 - Царев; 18 - Перегрузное-I; 19 - Ковалевка; 20 - Нижнедонская; 21 - Прохоровка.

Серии недеформированных черепов позднесарматского времени: 22 - Чиковский; 23 - Купцын Толга; 24 - Кермен Толга; 25 - Кузин; 26 - Первомайский; 27 - Нижнедонская 
В один и тот же кластер входят группы как раннесарматского времени, так и позднесарматского. Следует отметить, что все позднесарматские женские группы малочисленны (3-5 черепов), поэтому более достоверные выводы можно сделать по мере накопления материалов.

\section{Сравнительная характеристика серий среднесарматского и позднесарматскогои времени}

Мужские серии. Оценка статистической значимости различий средних и относительных величин при помощи $t$-критерия Стьюдента в данном случае осуществлялась между мужскими группами численностью 180 и 105 черепов. Рассчитанное значение критерия больше критического по 13 краниологическим признакам (см. табл. 1). При этом для большинства признаков уровень значимости в пределах 0,001 и 0,01. Как и при сравнении с раннесарматской серией, большая часть признаков связана с изменчивостью размеров мозговой коробки и их производными $(8 ; 8: 1$; $17: 8 ;$ М2; 11; 45:8). И только два признака отражают изменчивость горизонтальной профилировки лицевого скелета: это назомалярный и зигомаксилярный углы (77 и <zm'). Значимые различия, которые наблюдаются по ряду признаков лобной кости: лобно-поперечный указатель; угол поперечного изгиба лба, наибольшая ширина лба, широтный лобный указатель и угол профиля лба от назиона (9:8; УПИЛ; 10; 9:10; 32), - следует воспринимать как аналогичную направленность различий, что и при сравнении позднесарматских серий с раннесарматскими, то есть как возможное влияние деформирующей конструкции на лобную кость в позднесарматской группе. Кроме этого, если при сравнении серий ранне- и позднесарматского периодов достоверно значимые различия затрагивают все три тотальных размера черепной коробки $(1 ; 8$; 17), то во втором - только один: поперечный диаметр. Такое направление изменчивости между хронологическими группами можно объяснить тем, что среднесарматское население по параметрам мозговой коробки уже не столь резко отличается от позднесарматского. Что касается профильных углов лице- вого скелета, то различие также оправданно, так как среднесарматское население имеет умеренную профилировку лица, а позднесарматское - с резкую.

Результаты канонического анализа также свидетельствуют, с одной стороны, о различиях, а с другой - о частичном сходстве. Вклад первого канонического вектора (анализировались 22 и 17 групп) - 26,0 \% от общей изменчивости, и наиболее значимые различия выпадают на поперечный диаметр, симотический указатель и угол профиля носа (8; SS:SC; 75-1).

По этой дискриминанте наибольшие положительные значения имеют группы, у которых узкий череп с высокими носовыми костями, но нос выводят к линии профиля умеренно, а отрицательные нагрузки будут иметь группы с альтернативным набором. Ранжирование значений групп по этой переменной показывает, что сравниваемые хронологические серии расположились вперемешку.

Видимо, самые важные различия между средними и поздними сарматами отмечаются по двум признакам: поперечный диаметр и угол выступания носа, так как и по II КВ у них высокие корреляции (вклад его более 20,0 \%).

Информацию, которую можно извлечь по результатам многомерного кластерного анализа и неметрического шкалирования расстояний Махаланобиса, можно интерпретировать следующим образом. Мужское население позднесарматского и среднесарматского времени обладает большим сходством, чем раннесарматского и позднесарматского времени (рис. 5). Как сходство, так и различие, которое отчетливо видно на графике, можно отнести на счет локальных особенностей. Так, разновременные группы с могильников Волго-Донского междуречья (Первомайский, Асай, Перегрузное I и др.) и Астраханского правобережья (хутор Кузин, Старица, Кривая Лука) обладают сходством, а вот в регионах, где в большей степени сохраняется субстратный раннесарматский компонент (Заволжье), сходства не наблюдается.

Таким образом, динамика хронологической изменчивости отражает то, что в некоторых сарматских районах, в которых проживало длинноголовое раннесарматское население, новые группы мигрантов лишь частично изменили его облик. 


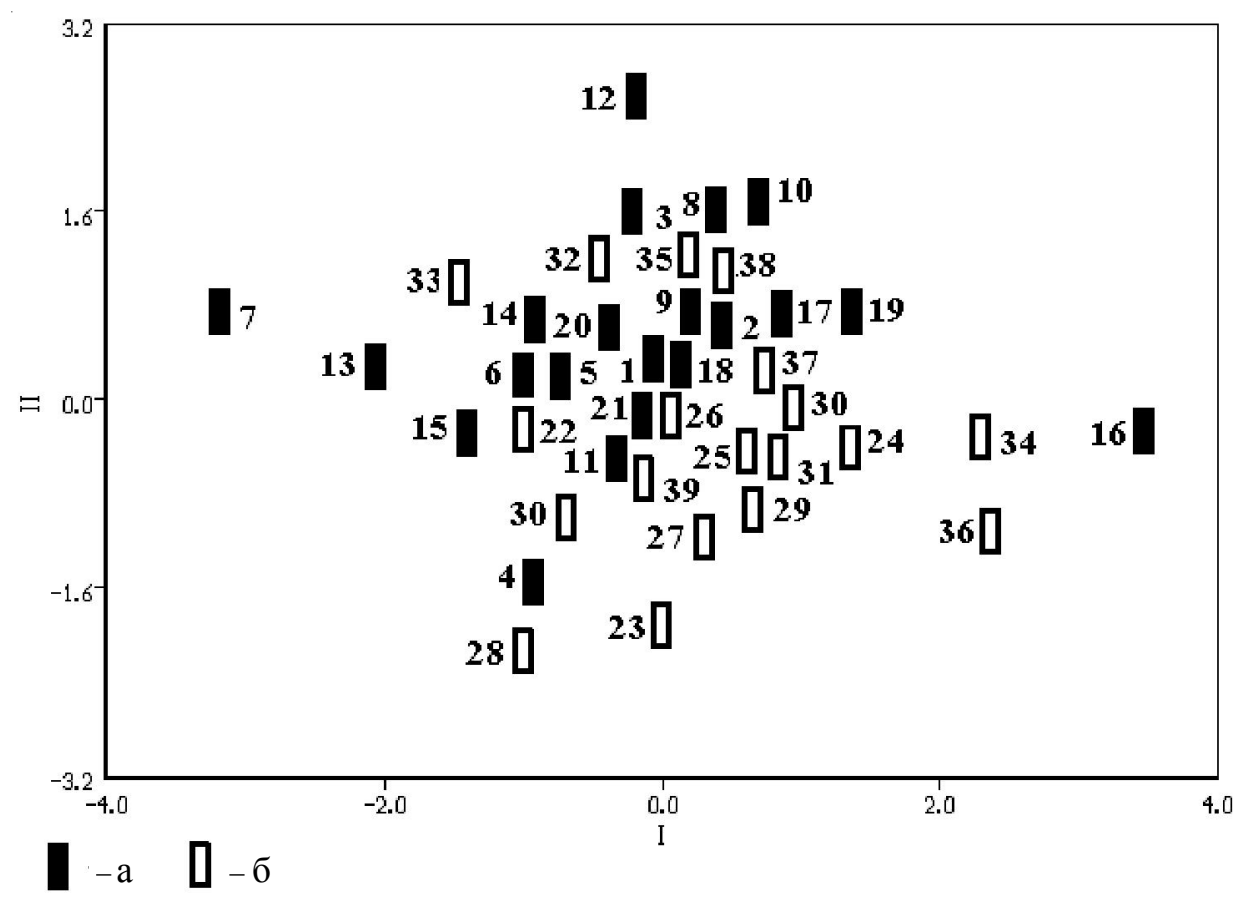

Рис. 5. Результат многомерного неметрического шкалирования расстояний близости по Махаланобису $\left(D^{2}\right)$ мужских серий среднесарматского и позднесарматского времени ( $a$ - серии среднесарматского времени; $\sigma$ - серии позднесарматского времени; объединены серии из одного могильника, образующие один кластер):

Серии среднесарматского времени: 1 - Терновский; 2 - Первомайский; 3 - Бережновка I; 4 - Кузин; 5 - Кривая Лука; 6 - Быково; 7 - Политотдельское; 8 - Бережновка II; 9 - Старица; 10 - Канал Волга-Чограй; 11 - Эвдык; 12 - Аккермень; 13 - Усть-Каменка; 14 - Новый; 15 - Колобовка; 16 - Калиновка-1; 17 - Перегрузное I; 18 - Аксай; 19 - Жутово; 20 - Нижнедонская 1; 21 - Нижнедонская.

Серии недеформированных черепов позднесарматского времени: 22 - Кузин; 23 - Джангр; 24 - Кривая Лука;

25 - Старица; 26 - Бережновка; 27 - Бережновка II; 28 - Бережновка I; 29 - Калиновка; 30 - Купцын Толга;

31 - Канал Волга-Чограй; 32 - Цаган-Усн; 33 - Абганерово II; 34 - Терновский; 35 - Аксай; 36 - Перегрузное I; 37 - Первомайский; 38 - Нижнедонская

Подводя итоги проведенного сравнительного анализа мужских групп всех трех сарматских периодов, можно говорить как о частичном сохранении морфологического типа на всех трех этапах, так и об изменениях, априори доказывающих приток новых групп мигрантов, носителей как нового культурного компонента, так и типа длинноголовых европеоидов. На среднем этапе, видимо, мигранты, кроме морфологического типа, сочетающего длинную высокосводчатую мозговую коробку с долихокранными пропорциями, обладали и умеренно профилированным лицом. На позднесарматском этапе это были уже длинноголовые европеоиды с резко выраженным расовым комплексом.

Женские серии. Женские серии, состоящие из 116 и 30 черепов, при сравнении по $t$-критерию Стьюдента тоже дали значимые различия только по одному признаку: это максилофронтальная ширина (МС) (см. табл. 2).
Результаты канонического анализа женских групп средних и поздних сарматов (18 и 6 групп) также показывают отличное от мужских групп распределение изменчивости. На I и II КВ выпадают различия между группами, которые связаны с разграничением широколицых групп с узкой и высокой глазницей и узколицых групп с широкой и низкой глазницей (I KB), а также широколицых с широким черепом и узколицых с узким черепом (II КВ). Большая часть серий обликом первого типа относится к среднесарматскому времени (Политотдельское, Ново-Филипповка, Аксай и др.), а второго - и к позднесарматскому (Купцын Толга, Кузин хутор), и к среднесарматскому (Крепь, Бережновка-II, Калиновка и др.). У групп, расположенных на положительном полюсе, скуловой диаметр выше 130 мм, ширина глазницы около 40 мм, а ее высота выше 33 мм. На противоположном полюсе будут 
группы, у которых скуловой диаметр ниже 130 мм, ширина глазницы выше 43 мм, а еe высота около 29 мм.

Таким образом, женские серии средних и поздних сарматов, как и в предыдущем случае, мало отличаются друг от друга по сравнению с мужскими (рис. 6).

\section{Заключение}

В заключение хотелось бы подвести итоги вышесказанного и дать реконструкцию возможного варианта развития антропологических типов на протяжении всей сарматской истории. Использование в реконструкциях массового материала позволяет довольно уверенно говорить о возможных событиях, которые, с одной стороны, сохраняли субстратный компонент, а с другой - «размывали» его.

Прежде всего, следует отметить, что значительные изменения морфологического облика претерпевала мужская часть населения. Женская же часть (кроме той группы поздне- го этапа, которая практиковала обычай деформации) сохраняла облик местного раннесарматского населения на протяжении IV-III вв. до н. э. - II-IV вв. н. э.

Динамика развития антропологических типов мужской части связана с миграционными волнами, которые сначала изменили у субстратного населения размеры и форму мозговой коробки, а затем и горизонтальную профилировку лица. Как известно, большая часть групп раннесарматского времени характеризуется умеренной профилировкой лицевого скелета только на верхнем уровне, а среднесарматского - и на верхнем, и на среднем. Таким образом, значимое различие между этими группами по зигомаксилярному углу становится вполне объяснимым. Очевидно, это связано с какими-то группами восточных мигрантов, которые не только отличались более длинной и узкой черепной коробкой с мезодолихокранными пропорциями и высоким сводом, но и умеренной профилировкой лицевого скелета на обоих уровнях.

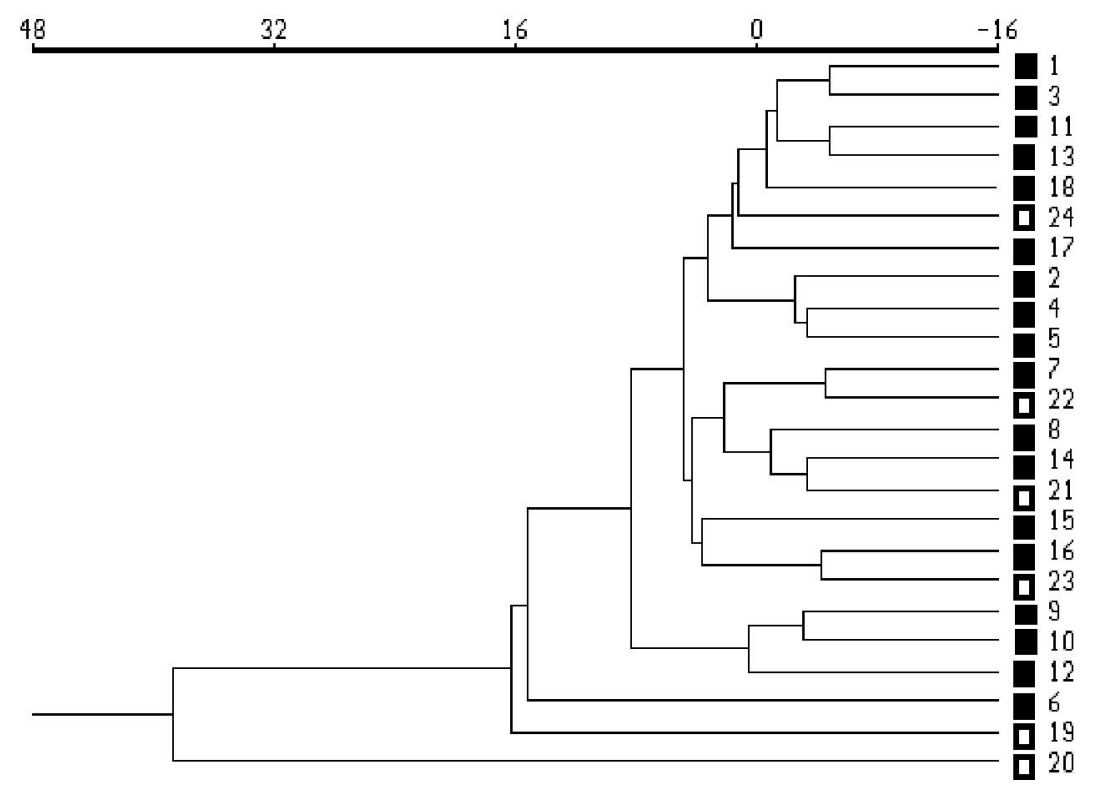

$-\mathrm{a} \quad \boldsymbol{\square}-6$

Рис. 6. Результат кластеризации расстояний близости по Махаланобису $\left(D^{2}\right)$ женских серий среднесарматского и позднесарматского времени ( $a$ - серии среднесарматского времени; $\sigma$ - серии позднесарматского времени):

Серии среднесарматского времени: 1 - Бережновка I; 2 - Бережновка II; 3 - Калиновка; 4 - Калиновка-1; 5 - Крепь; 6 - Первомайский; 7 - Старица; 8 - Новый; 9 - Ново-Филипповка; 10 - Аккермень; 11 - Колобовка;

12 - Политотдельское; 13 - Усть-Каменка; 14 - Перегрузное I; 15 - Аксай; 16 - Терновский; 17 - Нижнедонская-1; 18 - Нижнедонская.

Серии недеформированных черепов позднесарматского времени: 19 - Чиковский; 20 - Купцын Толга; 21 - Кермен Толга; 22 - Кузин; 23 - Первомайский; 24 - Нижнедонская 
Как показывает материал, первая волна мигрантов с востока пришла на Волгу, скорее всего, еще во II-I вв. до н. э., так как именно в это время увеличивается доля длинноголовых европеоидов в сериях по сравнению с предшествующим временем - IV-III вв. до н. э. Кроме предполагаемого сценария, в формировании позднесарматского населения, видимо, участвовали и другие группы кочевников, которые были носителями типа длинноголовых европеоидов, этим и объясняются существенные различия между поздними и средними сарматами по обоим горизонтальным углам лицевого скелета. Не исключено, что это тоже были восточные группы, но из других территорий, нежели группы, участвовавшие в формировании средних сарматов.

Небольшая монголоидная примесь, которая фиксируется в основном на женском материале, позволяет предположить, что вместе с мужчинами в миграциях участвовала не только какаято группа женщин, обладающих типом длинноголовых европеоидов, но и те, у которых была монголоидная примесь. Периодические, преимущественно мужские, миграции на исконно сарматскую территорию на протяжении веков (c IVIII до н. э. до II-IV вв. н. э.) как привносили культурные новации, так и изменяли физический облик населения. Тем не менее на протяжении столетий, особенно у женской части населения, сохранялся «исконно сарматский тип»- тип умеренно широкоголовых европеоидов.

\section{СПИСОК ЛИТЕРАТУРЫ}

1. Балабанова, М. А. Антропология древнего населения Южного Приуралья и Нижнего Поволжья. Ранний железный век / М. А. Балабанова. М. : Наука, 2000. - 133 c.

2. Балабанова, М. А. Антропология сарматских диагональных погребальных комплексов / М. А. Балабанова // Нижневолжский археологический вестник. - 2002. - Вып. 5. - С. 82-94.

3. Балабанова, М. А. Об антропологических «перехлестах» в савроматской и сарматских культурах / М. А. Балабанова // Сарматские культуры Евразии: Проблемы региональной хронологии : докл. к 5 Междунар. конф. «Проблемы сарматской археологии и истории». - Краснодар : Фирма НСС, 2004. - C. 221-227.

4. Балабанова, М. А. Антропологические особенности сарматов локальной группы могильников
Есауловского Аксая (V в. до н. э. - 1-я половина II в. н. э.) / М. А. Балабанова // Нижневолжский археологический вестник. - 2006. - Вып. 8. - С. 110-138.

5. Батиева, Е. Ф. Население Нижнего Дона в IX в. до н. э. - IV в. н. э. (палеоантропологическое исследование) / Е. Ф. Батиева. - Ростов н/Д : Изд-во ЮНЦРАН, 2011. $-160 \mathrm{c}$.

6. Безуглов, С. И. Курганные катакомбные погребения позднеримской эпохи в нижнедонских степях / С. И. Безуглов // Проблемы современной археологии : сб., посвящ. памяти В. А. Башилова. M. : Tayc, 2008. -C. 284-301.

7. Безуглов, С. И. Позднесарматская культура и Нижний Дон (современное состояние проблемы) / С. И. Безуглов // Становление и развитие позднесарматской культуры : сб. науч. ст. - Волгоград : Изд-во Волгу, 2010. - С. 93-116. - (Материалы семинара Центра изучения истории и культуры сарматов : вып. III).

8. Глебов, В. П. Хронология раннесарматской и среднесарматской культур Нижнего Подонья / В. П. Глебов // Сарматские культуры Евразии: Проблемы региональной хронологии : докл. к 5 Междунар. конф. «Проблемы сарматской археологии и истории». - Краснодар : Фирма НСС, 2004. - С. 127-133.

9. Глебов, В. П. К полемике о проблемах становления среднесарматской культуры / В. П. Глебов // Раннесарматская и среднесарматская культуры: проблемы соотношения / отв. ред. В. М. Клепиков. - Волгоград : Волгогр. науч. изд-во, 2006. С. 59-68. - (Материалы семинара Центра изучения истории и культуры сарматов ; вып. I).

10. Граков, Б. Н. Пережитки матриархата у сарматов / Б. Н. Граков // ВДИ. - 1947. -№ 3. - С. 100-121.

11. Гуцалов, С. Ю. К проблеме стыка прохоровской и сусловской культур в степях Южного Урала / С. Ю. Гуцалов // Раннесарматская и среднесарматская культуры: проблемы соотношения / отв. ред. В. М. Клепиков. - Волгоград : Волгогр. науч. издво, 2006. - С. 69-88. - (Материалы семинара Центра изучения истории и культуры сарматов ; вып. I).

12. Дебец, Г. Ф. Материалы по палеоантропологии СССР. Нижнее Поволжье / Г. Ф. Дебец // АЖ. 1936. - № 1. - C. $65-80$.

13. Клепиков, В. М. Археологические исследования курганного могильника Перегрузное I / В. М. Клепиков, М. В. Кривошеев, А. Н. Дьяченко // Курганный могильник Перегрузное I: результаты междисциплинарного исследования. - Волгоград : Изд-во Волгогр. фил. ФГБОУ ВПО РАНХиГС, 2014. - C. 9-217.

14. Кривошеев, М.В.Вопросы происхождения и развития позднесарматской культуры в Нижнем Поволжье / М. В. Кривошеев // Становление и развитие позднесарматской культуры : сб. науч. ст. Волгоград : Изд-во ВолГУ, 2010. - С. 57-92. - (Мате- 
риалы семинара Центра изучения истории и культуры сарматов : вып. III).

15. Кривошеев, М. В. Позднесарматская культура междуречья Волги и Дона. Проблема становления и развития / М. В. Кривошеев, А. С. Скрипкин // РА. - 2006. - № 1. - С. 124-136.

16. Малашев, В. Ю. Позднесарматская культура: верхняя хронологическая граница / В. Ю. Малашев // PA. - 2009. - № 1. - C. 47-52.

17. Малашев, В. Ю. Центральные районы Северного Кавказа в позднесарматское время / В. Ю. Малашев // Становление и развитие позднесарматской культуры : сб. науч. ст. - Волгоград : Изд-во ВолГУ, 2010. - С. 117-142. - (Материалы семинара Центра изучения истории и культуры сарматов : вып. III).

18. Мошкова, М. Г. Среднесарматские и позднесарматские памятники на территории Южного Приуралья / М. Г. Мошкова // Сарматские культуры Евразии: Проблемы региональной хронологии : докл. к 5 Междунар. конф. «Проблемы сарматской археологии и истории. - Краснодар : Фирма НCC, 2004. - C. 22-44.

19. Мошкова, М. Г. Анализ сарматских погребальных памятников II-IV вв. н. э. / М. Г. Мошкова // Позднесарматская культура. - М. : Восточная литература, 2009. - С. 21-162. - (Статистическая обработка погребальных памятников Азиатской Сарматии ; вып. IV).

20. Раев, Б. А. О времени первого появления аланов в юго-восточной Европе / Б. А. Раев, С. А. Яценко // Скифия и Боспор : тез. докл. Междунар. конф. Новочеркасск : [б. и.], 1993. - С. 111-126.

21. Сергацков, И. В. Анализ сарматских погребальных памятников в I-ІІ вв. н. э. / И. В. Сергацков // Среднесарматская культура. - М. : Восточная литература, 2002. - С. 22-129. - (Статистическая обработка погребальных памятников Азиатской Сарматии ; вып. III).

22. Сергацков, И. В. Проблема становления среднесарматской культуры / И. В. Сергацков // Раннесарматская и среднесарматская культуры: проблемы соотношения / отв. ред. В. М. Клепиков. Волгоград : Волгогр. науч. изд-во, 2006. - С. 37-58. (Материалы семинара Центра изучения истории и культуры сарматов ; вып. I).

23. Скрипкин, А. С. Азиатская Сарматия. Проблемы хронологии и ее исторический аспект / А. С. Скрипкин. - Саратов : Изд-во СГУ, 1990.$299 \mathrm{c}$.

24. Скрипкин, А. С. К проблеме соотношения ранне- и среднесарматских культур / А. С. Скрипкин // Раннесарматская и среднесарматская культуры: проблемы соотношения / отв. ред. В. М. Клепиков. - Волгоград : Волгогр. науч. изд-во, 2006. С. 5-36. - (Материалы семинара Центра изучения истории и культуры сарматов ; вып. I).
25. Смирнов, К. Ф. Сарматские курганные погребения в степях Поволжья и Южного Приуралья / К. Ф. Смирнов // Доклады и сообщения исторического факультета. - Вып. 5. - М. : Изд-во МГУ, 1947. - С. 75-80.

26. Фирштейн, Б. В. Сарматы Нижнего Поволжья в антропологическом освещении / Б. В. Фирштейн // Антропологические данные к вопросу о великом переселении народов. Авары и сарматы / Т. А. Тот, Б. В. Фирштейн. - Л. : Наука, 1970. C. 69-201.

\section{REFERENCES}

1. Balabanova M.A. Antropologiya drevnego naseleniya Yuzhnogo Priuralya $i$ Nizhnego Povolzhya. Ranniy zheleznyy vek [Anthropology of the Ancient Population of the Southern Urals and the Lower Volga Region. Early Iron Age]. Moscow, Nauka Publ., 2000. 133 p.

2. Balabanova M.A. Antropologiya sarmatskikh diagonalnykh pogrebalnykh kompleksov [Anthropology of Sarmatian Diagonal Burial Complexes]. Nizhnevolzhskiy arkheologicheskiy vestnik, 2002, iss. 5, pp. 82-94.

3. Balabanova M.A. Ob antropologicheskikh "perekhlestakh" v savromatskoy i sarmatskikh kulturakh [On the Anthropological "Overlaps" in Sauromatian and Sarmatian Cultures]. Sarmatskie kultury Evrazii: Problemy regionalnoy khronologii : dokl. k 5 Mezhdunar. konf. "Problemy sarmatskoy arkheologii i istorii" [Sarmatian Cultures of Eurasia: Problems of Regional Chronology. Reports to the 5th International Conference "Problems of Sarmatian Archaeology and History"]. Krasnodar, Firma NSS Publ., 2004, pp. 221-227.

4. Balabanova M.A. Antropologicheskie osobennosti sarmatov lokalnoy gruppy mogilnikov Esaulovskogo Aksaya (V v. do n. e. - 1-ya polovina II v. n.e.) [Anthropological Features of Sarmatians of the Local Group of Esaulovsky Aksai Burial Mounds (5th c. BC-first half of the 2nd c. AD)]. Nizhnevolzhskiy arkheologicheskiy vestnik, 2006, iss. 8, pp. 110-138.

5. Batieva E.F. Naselenie Nizhnego Dona $v I X v$. do n.e. - IV v. n.e. (paleoantropologicheskoe issledovanie) [The Population of the Lower Don in the 9th c. BC. -4 th c. AD (Paleoanthropological Research)]. Rostov-on-Don, YuNTs RAN Publ., 2011. $160 \mathrm{p}$.

6. Bezuglov S.I. Kurgannye katakombnye pogrebeniya pozdnerimskoy epokhi v nizhnedonskikh stepyakh [Catacomb Burial Mounds of Late Roman Era in the Lower Don Steppes]. Problemy sovremennoy arkheologii. Sbornik, posvyashchennyy pamyati V.A. Bashilova [Problems of Modern Archaeology. 
Collection Dedicated to the Memory of V.A. Bashilov]. Moscow, Taus Publ., 2008, pp. 284-301.

7. Bezuglov S.I. Pozdnesarmatskaya kultura i Nizhniy Don (sovremennoe sostoyanie problemy) [Late Sarmatian Culture and Lower Don (Current State of Problem)]. Stanovlenie i razvitie pozdnesarmatskoy kultury (Materialy seminara Tsentra izucheniya istorii i kultury sarmatov: vyp. III). Sbornik nauchnykh statey [Formation and Development of the Late Sarmatian Culture (Proceedings of the Seminar of the Center of Studying the History and Culture of the Sarmatians: Iss. 3). Collected Scientific Articles]. Volgograd, 2010, pp. 93-116.

8. Glebov V.P. Khronologiya rannesarmatskoy i srednesarmatskoy kultur Nizhnego Podonya [Chronology of Early and Mid Sarmatian Cultures of the Lower Don Region]. Sarmatskie kultury Evrazii: Problemy regionalnoy khronologii: dokl. $k$ 5 Mezhdunar. konf. "Problemy sarmatskoy arkheologii i istorii" "[Sarmatian Cultures of Eurasia: Problems of Regional Chronology. Procedings of the 5th International Conference "Problems of Sarmatian Archaeology and History"]. Krasnodar, Firma NSS Publ., 2004, pp. 127-133.

9. Glebov V.P. K polemike o problemakh stanovleniya srednesarmatskoy kultury [Debate on the Problems of Mid Sarmatian Culture Formation]. Klepikov V.M., ed. Rannesarmatskaya $i$ srednesarmatskaja kultury: problemy sootnosheniya (Materialy seminara Tsentra izucheniya istorii $i$ kultury sarmatov: vyp. I) [Early and Mid Sarmatian Cultures: Problems of Correlation (Proceedings of the Seminar of the Center of Studying the History and Culture of the Sarmatians: Iss. 1)]. Volgograd, 2006, pp. 59-68.

10. Grakov B.N. Perezhitki matriarkhata u sarmatov [The Remnants of Sarmatian Matriarchy]. VDI, 1947, no. 3 , pp. 100-121.

11. Gutsalov S.Yu. K probleme styka prokhorovskoy i suslovskoy kultur v stepyakh Yuzhnogo Urala [On the Problem of Joint Prokhorov and Suslov Cultures in the Steppes of Southern Urals]. Klepikov V.M., ed. Rannesarmatskaya $i$ srednesarmatskaja kultury: problemy sootnosheniya (Materialy seminara Tsentra izucheniya istorii $i$ kultury sarmatov: vyp. I) [Early and Mid Sarmatian Cultures: Problems of Correlation (Proceedings of the Seminar of the Center of Studying the History and Culture of the Sarmatians: Iss. 1)]. Volgograd, Volgogr. nauch. izd-vo, 2006, pp. 69-88.

12. Debets G.F. Materialy po paleoantropologii SSSR. Nizhnee Povolzhye [Materials on Paleoanthropology of the USSR. Lower Volga Region]. $A Z h, 1936$, no. 1, pp. 65-80.

13. Klepikov V.M., Krivosheev M.V., Dyachenko A.N. Arkheologicheskie issledovaniya kurgannogo mogilnika Peregruznoe I [Archaeological Studies of Peregruznoe I Burial Mound]. Kurgannyy mogilnik Peregruznoe I: rezultaty mezhdistsiplinarnogo issledovaniya [Peregruznoe I Burial Mound: Results of Interdisciplinary Research]. Volgograd, Izd-vo Volgogr. fil. FGBOUVPO RANKhiGS, 2014, pp. 9-217.

14. Krivosheev M.V. Voprosy proiskhozhdeniya i razvitiya pozdnesarmatskoy kultury v Nizhnem Povolzhye [The Origin and Development of the Late Sarmatian Culture in the Lower Volga Region]. Stanovlenie i razvitie pozdnesarmatskoy kultury (Materialy seminara Tsentra izucheniya istorii $i$ kultury sarmatov: vyp. III): sb. nauch. st. [Formation and Development of the Late Sarmatian Culture (Proceedings of the Seminar of the Center of Studying the History and Culture of the Sarmatians: Iss. 3). Collected Scientific Articles]. Volgograd, Izd-vo VolGU, 2010, pp. 57-92.

15. Krivosheev M.V., Skripkin A.S. Pozdnesarmatskaya kultura mezhdurechya Volgi i Dona. Problema stanovleniya i razvitiya [Late Sarmatian Culture Between the Volga and Don Rivers. The Problem of Formation and Development]. RA, 2006, no. 1, pp. 124-136.

16. Malashev V.Yu. Pozdnesarmatskaya kultura: verkhnyaya khronologicheskaya granitsa [Late Sarmatian Culture: Upper Chronological Boundary]. $R A, 2009$, no. 1, pp. 47-52.

17. Malashev V.Yu. Tsentralnye rayony Severnogo Kavkaza v pozdnesarmatskoe vremya [The Central Regions of the North Caucasus in the Late Sarmatian Age]. Stanovlenie $i$ razvitie pozdnesarmatskoy kultury (Materialy seminara Tsentra izucheniya istorii i kultury sarmatov: vyp. III): sb. nauch. st. [Formation and Development of the Late Sarmatian culture (Proceedings of the Seminar of the Center of Studying the History and Culture of the Sarmatians: Iss. 3). Collected Scientific Articles]. Volgograd, Izd-vo VolGU, 2010, pp.117-142.

18. Moshkova M.G. Srednesarmatskie i pozdnesarmatskie pamyatniki na territorii Yuzhnogo Priuralya [Mid and Late Sarmatian Monuments in the Southern Urals]. Sarmatskie kultury Evrazii: Problemy regionalnoy khronologii: doklady $k 5$ Mezhdunar. konf. "Problemy sarmatskoy arkheologii $i$ istorii" [Sarmatian Cultures of Eurasia: Problems of Regional Chronology: Reports of the 5th International Conference "Problems of Sarmatian Archaeology and History"]. Krasnodar, Firma NSS Publ., 2004, pp. 22-44.

19. Moshkova M.G. Analiz sarmatskikh pogrebalnykh pamyatnikov II-IV vv. n. e. [The Analysis of Sarmatian Burial Sites of the 2nd-4th Centuries BC]. Pozdnesarmatskaya kultura. Statisticheskaya obrabotka pogrebalnykh pamyatnikov Aziatskoy Sarmatii. Vyp. IV [Late Sarmatian Culture. Statistical Analysis of Burial Sites of Asian 


\section{АРХЕОЛОГИЯ}

Sarmatia. Iss. IV.]. Moscow, Vostochnaya Literatura Publ., 2009, pp. 21-162.

20. Raev B.A., Yatsenko S.A. O vremeni pervogo poyavleniya alanov v yugo-vostochnoy Evrope [On the Time of the First Appearance of the Alans in the South-East Europe]. Skifiya i Bospor: tez. dokl. Mezhdunar. konf [Scythia and the Bosporus. Proceedings of Reports of the International Conference]. Novocherkassk, 1993, pp. 111-126.

21. Sergatskov I.V. Analiz sarmatskikh pogrebalnykh pamyatnikov v I-II vv. n. e. [The Analysis of the Sarmatian Burial Sites in the 1st-2nd Centuries AD]. Pozdnesarmatskaya kultura. Statisticheskaya obrabotka pogrebalnykh pamyatnikov Aziatskoy Sarmatii. Vyp. III [Late Sarmatian Culture. Statistical Analysis of Burial Sites of Asian Sarmatia. Iss. III.]. Moscow, Vostochnaya literatura Publ., 2002, pp. 22-129.

22. Sergatskov I.V. Problema stanovleniya srednesarmatskoy kultury [The Problem of Sarmatian Culture Formation]. Rannesarmatskaya $i$ srednesarmatskaja kultury: problemy sootnosheniya (Materialy seminara Tsentra izucheniya istorii $i$ kultury sarmatov: vyp. I) [Early and Mid Sarmatian Cultures: Problems of Correlation (Proceedings of the Seminar of the Center of Studying the History and Culture of the Sarmatians: Iss. 1)]. Volgograd, Volgogr. nauch. izd-vo, 2006, pp. 37-58.
23. Skripkin A.S. Aziatskaya Sarmatiya. Problemy khronologii i ee istoricheskiy aspekt [Asian Sarmatia. Problems of Chronology and Its Historical Aspect]. Saratov, Izd-vo SGU, 1990. 299 p.

24. Skripkin A.S. K probleme sootnosheniya rannei srednesarmatskikh kultur [On the Problem ofCorrelation Between Early and Mid Sarmatian Cultures]. Rannesarmatskaya i srednesarmatskaja kultury: problemy sootnosheniya (Materialy seminara Tsentra izucheniya istorii i kultury sarmatov: vyp. I) [Early and Mid Sarmatian Cultures: Problems of Correlation (Proceedings of the Seminar of the Center of Studying the History and Culture of the Sarmatians: Iss. 1)]. Volgograd, Volgogr. nauch. izd-vo, 2006, pp. 5-36.

25. Smirnov K.F. Sarmatskie kurgannye pogrebeniya v stepyakh Povolzhya i Yuzhnogo Priuralya [Sarmatian Burial Mounds in the Steppes of the Volga and Southern Urals]. Doklady $i$ soobshcheniya istoricheskogo fakulteta [Reports of the Faculty of History]. Moscow, Izd-vo MGU, 1947, iss. 5, pp. 75-80.

26. Firshteyn B.V. Sarmaty Nizhnego Povolzhya v antropologicheskom osveshchenii [Lower Volga Sarmatians in the Anthropological Light]. Tot T.A., Firshteyn B.V. Antropologicheskie dannye $k$ voprosu o velikom pereselenii narodov. Avary $i$ sarmaty [Anthropological Data to the Issue of the Great Migration. Avares and Sarmatians]. Leningrad, Nauka Publ., 1970, pp. 69-201. 